\title{
Microglial Turnover in Ageing-Related Neurodegeneration: Therapeutic Avenue to Intervene in Disease Progression
}

\author{
Shofiul Azam ${ }^{1}$ (D), Md. Ezazul Haque ${ }^{1}\left(\mathbb{D}\right.$, In-Su Kim ${ }^{2}$ and Dong-Kug Choi ${ }^{1,2, *(D)}$ \\ 1 Department of Applied Life Science \& Integrated Bioscience, Graduate School, BK21 Program, \\ Konkuk University, Chungju 27478, Korea; shofiul_azam@hotmail.com (S.A.); \\ mdezazulhaque@yahoo.com (M.E.H.) \\ 2 Department of Integrated Bioscience \& Biotechnology, College of Biomedical and Health Science, \\ Research Institute of Inflammatory Disease (RID), Konkuk University, Chungju 27478, Korea; \\ kis5497@hanmail.net \\ * Correspondence: choidk@kku.ac.kr; Tel.: +82-43-840-3610; Fax: +82-43-840-3872
}

Citation: Azam, S.; Haque, M.E. Kim, I.-S.; Choi, D.-K. Microglial Turnover in Ageing-Related Neurodegeneration: Therapeutic Avenue to Intervene in Disease Progression. Cells 2021, 10, 150. https://doi.org/10.3390/cells10010150

Received: 24 November 2020

Accepted: 11 January 2021

Published: 14 January 2021

Publisher's Note: MDPI stays neutral with regard to jurisdictional clai$\mathrm{ms}$ in published maps and institutional affiliations.

Copyright: $(\odot 2021$ by the authors. Licensee MDPI, Basel, Switzerland. This article is an open access article distributed under the terms and conditions of the Creative Commons Attribution (CC BY) license (https:// creativecommons.org/licenses/by/ $4.0 /)$.

\begin{abstract}
Microglia are brain-dwelling macrophages and major parts of the neuroimmune system that broadly contribute to brain development, homeostasis, ageing and injury repair in the central nervous system (CNS). Apart from other brain macrophages, they have the ability to constantly sense changes in the brain's microenvironment, functioning as housekeepers for neuronal wellbeing and providing neuroprotection in normal physiology. Microglia use a set of genes for these functions that involve proinflammatory cytokines. In response to specific stimuli, they release these proinflammatory cytokines, which can damage and kill neurons via neuroinflammation. However, alterations in microglial functioning are a common pathophysiology in age-related neurodegenerative diseases, such as Alzheimer's, Parkinson's, Huntington's and prion diseases, as well as amyotrophic lateral sclerosis, frontotemporal dementia and chronic traumatic encephalopathy. When their sentinel or housekeeping functions are severely disrupted, they aggravate neuropathological conditions by overstimulating their defensive function and through neuroinflammation. Several pathways are involved in microglial functioning, including the Trem2, Cx3cr1 and progranulin pathways, which keep the microglial inflammatory response under control and promote clearance of injurious stimuli. Over time, an imbalance in this system leads to protective microglia becoming detrimental, initiating or exacerbating neurodegeneration. Correcting such imbalances might be a potential mode of therapeutic intervention in neurodegenerative diseases.
\end{abstract}

Keywords: microglia; neurodegeneration; neuroinflammation; macrophages; homeostasis

\section{Introduction}

Microglia are brain-dwelling parenchymal macrophages [1] that are distinct from other brain-dwelling non-parenchymal macrophagic populations and tissue macrophages [2,3]. Under healthy and normal conditions, microglia are self-maintained with no considerable contribution of peripheral myeloid cells [4]. In addition, $\sim 5 \%$ of the total cells of the neocortex are normally microglial [5]. These macrophages have a uniform distribution throughout the central nervous system (CNS) parenchyma, with a population of approximately $10 \%$ of the total cells in the CNS. In addition, they can form a cellular grid with their ramified and highly motile process [6]. During the developmental phase of the brain, microglia help shape neural circuits by modulating the strength of synaptic transmissions and sculpting neuronal synapses. When sensing any CNS injury, they become phagocytic and eliminate microbes, cell debris, protein aggregates or any form of CNS insult. However, microglial activation has been reported during several neurological conditions [7,8], in which they have evidently been playing both beneficial and detrimental roles, depending on disease progression. 
The correct functioning of microglia is necessary for neural circuit remodelling and synaptic function, but their involvement in the pathogenesis of neurological diseases raises the debate of whether microglial activation is beneficial or detrimental. In response to CNS insults, microglia proliferate rapidly [9], but their proliferation and turnover rates under homeostatic conditions have not been well documented. Filling this research gap could differentiate them from disease-causing agents [10]. Several studies have shown interesting but conflicting results, either very low or very high microglial turnover in mice and the post-mortem brain [11-13], although the validity of these techniques has been arguable and limited [14,15]. However, it is clear that understanding the regulation of microglial populations in the brain is crucial to understanding their functioning at different phases of age and age-related diseases. In one case, the mouse model of AD showed that early priming of individual microglia can induce long-lasting functional changes in life, whereas microglial senescence may have a role in age-related neurodegeneration [10]. For example, stimulation of the brain's immune system during development can induce long-lasting changes in microglial immune responses [16,17], and ageing and senescence of microglia contribute to neurodegenerative disorders [18].

However, changes in microglial homeostasis and functioning during age and agerelated neurodegenerative diseases could be due to alterations in the brain's microenvironment or to the longevity of microglia, possibilities that remain unclear. Therefore, this article will discuss in detail microglia's physiological role and changes due to exposure to different insults in individual age-related neurodegeneration.

\section{Molecular and Functional Background of Microglia}

Microglia are the resident immune cells of the brain and cover almost $5-12 \%$ of CNS cells [19]. In addition, microglia are involved in the homeostasis of host defence against pathogens and consequent neurological disorders [20,21]. These cells are mesenchymal, originating in the yolk sac, and do not require hematopoietic stem cells for renewal $[13,22]$. Their survival and maintenance depend on cytokines, including CSF1 and interleukin (IL)-34 [23], and on transcription factors such as IRF8 [22]. However, microglia can be simply defined as innate immune cells of the CNS that originate from myeloid cells and express several genes, including Cx3cr1, CD11b, Iba1 and F4/80 [21]. Depending on comprehensive knowledge of microglial gene expression and relevant functions [21,24], this study attempted to determine microglial functions in accordance with their gene expressions. There are three basic functions of microglia-sensing their environment, maintaining physiological homeostasis and protecting against self-modified and exogenous injurious agents. Furthermore, these normal functions are important regulators from a human being's embryonic stages through to old age.

Sensing is the primary requirement for microglia to function in housekeeping and defending their host from injury (Figure 1). Microglia form a network that spans throughout the CNS. Their thin processes are dynamic and in constant motion, allowing them to scan the area surrounding their cell body every few hours and rapidly polarise toward focal injury $[8,19]$. This network includes approximately 100 or more genes that consistently scan surrounding cell bodies and sense any changes in their microenvironment [24-26]. The sensome mRNA is expressed uniformly in microglia of different regions of the brain, indicating that all microglia are capable of sensing functions.

The second and most important part of microglial function is physiological homeostasis. This function includes synaptic remodelling such as CNS development and maintenance, neurodegeneration $[27,28]$, phagocytosis of dead or malfunctioning neuronal cells or cell debris [29,30], or myelin homeostasis [31] (Figure 2). In addition, microglia activate several inflammatory pathways that cause neuroinflammation and possibly neurodegeneration. In this process, microglia interact with astrocytes, and their interaction is also important in regulating homeostasis. Several chemokine and chemoattractant housekeeping genes are involved in phagocytosis (Trem2), synaptic pruning and remodelling ( $\mathrm{C} 1 q$ and Cx3cr1) [24], and anomalies in these housekeeping genes may lead to neurodegeneration. 


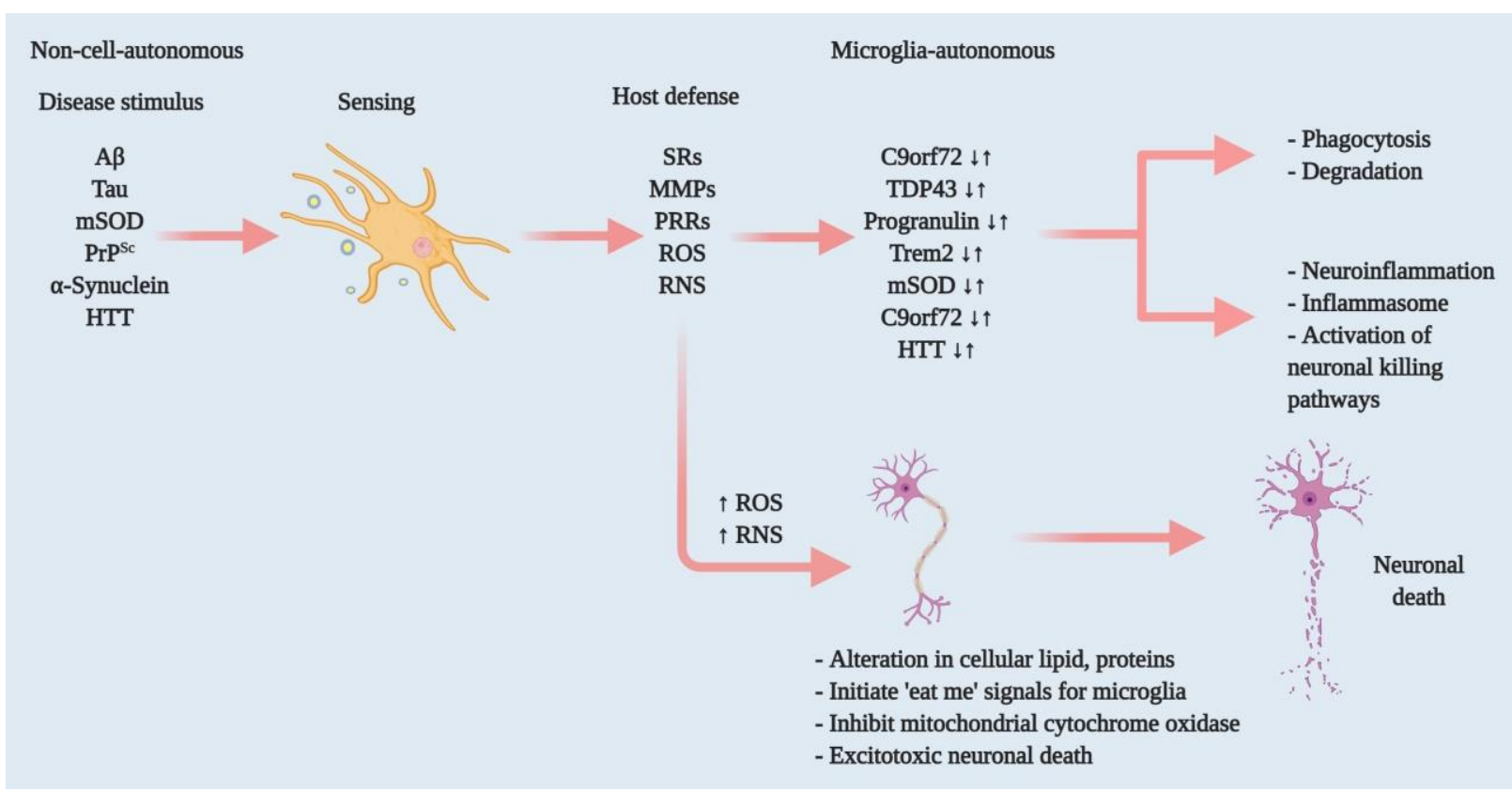

Figure 1. Effectors of microglia function associated with neurodegeneration and how microglia damage or kills neurons. Microglia have both host-defensive and detrimental actions, depending on the scenario. When they encounter aberrant or misfolded proteins—such as $\mathrm{A} \beta$, aggregated $\alpha$-synuclein, oxidised or $\mathrm{mSOD} 1$, or $\mathrm{PrP}^{\mathrm{Sc}}$ - they function as sentinels, protective hosts. In response to these toxic stimuli, microglia attempt to clear aggregated A $\beta, \alpha$-synuclein or mSOD1 via SRs and other PRRs. However, the nature of the aberrant proteins or their continued production disrupts microglial housekeeping functions. Several pathways activate: NADPH oxidase produces superoxide and derivative oxidants; iNOS produces nitric oxide derivatives, glutamate, cathepsin B and other proteases, and that produces stressed neurons. These processes dysregulate the microglial host-defensive mechanism, leading to an exaggerated proinflammatory response, neurotoxicity and neurodegeneration. Microglia also include tumour necrosis factor (TNF) as an indirect pathway to damage or kill neurons via reducing brain-derived neurotrophic factor (BDNF) and insulin-like growth factor (IGF) production. Neurodegenerative diseases such as AD, ALS and HD, furthermore, cause mutations in specific genes that lead to self-autonomous dysregulation of host defence. This initiates or exaggerates proinflammatory responses, resulting in neurotoxicity and neurodegeneration. In this way, when mutations in TDP-43, progranulin and Trem 2 increase ( $\uparrow)$, they affect phagocytosis and associated degradation pathways. Similarly, mutations in mSOD and HTT ( $\uparrow$ ) also affect inflammasome activation and neuronal killing pathways. On the other hand, mutations in C9orf72 can affect both phagocytosis and inflammasome pathways. In normal physiology, a microglia-autonomous mechanism controls the scenario by clearing $(\downarrow)$ mutant or aberrant proteins (adapted from ref. [8]).

As carriers of innate immunity, microglia defend their host against pathogens (Figure 1), injurious proteins including $\mathrm{A} \beta$, aggregated $\alpha$-synuclein, mutant huntingtin $(\mathrm{mHtt})$, mutant prion $\left(\mathrm{mPrP}^{\mathrm{Sc}}\right)$ and oxidised superoxide dismutase (SOD). Microglia activate several receptors to incite host defences, such as expressing Fc receptors, Toll-like receptors (TLRs), and several antimicrobial peptides including Camp and Ngp [24]. Therefore, microglia approach the neuroinflammatory threshold by producing peripheral inflammatory cytokines such as TNF- $\alpha$ and IL-1 $\beta$ [33,34]. In addition, this process involves chemokines (e.g., Ccl2) that recruit additional cells and work together to clear pathogens and normalise the brain in a homeostatic condition [35]. However, consistent microglia-induced neuroinflammation leads to neurotoxicity and, eventually, neurodegeneration. In contrast to the anomalies in this microglial functioning, healthy neural microglia are always actively functioning through sensing, housekeeping and protecting their host. 


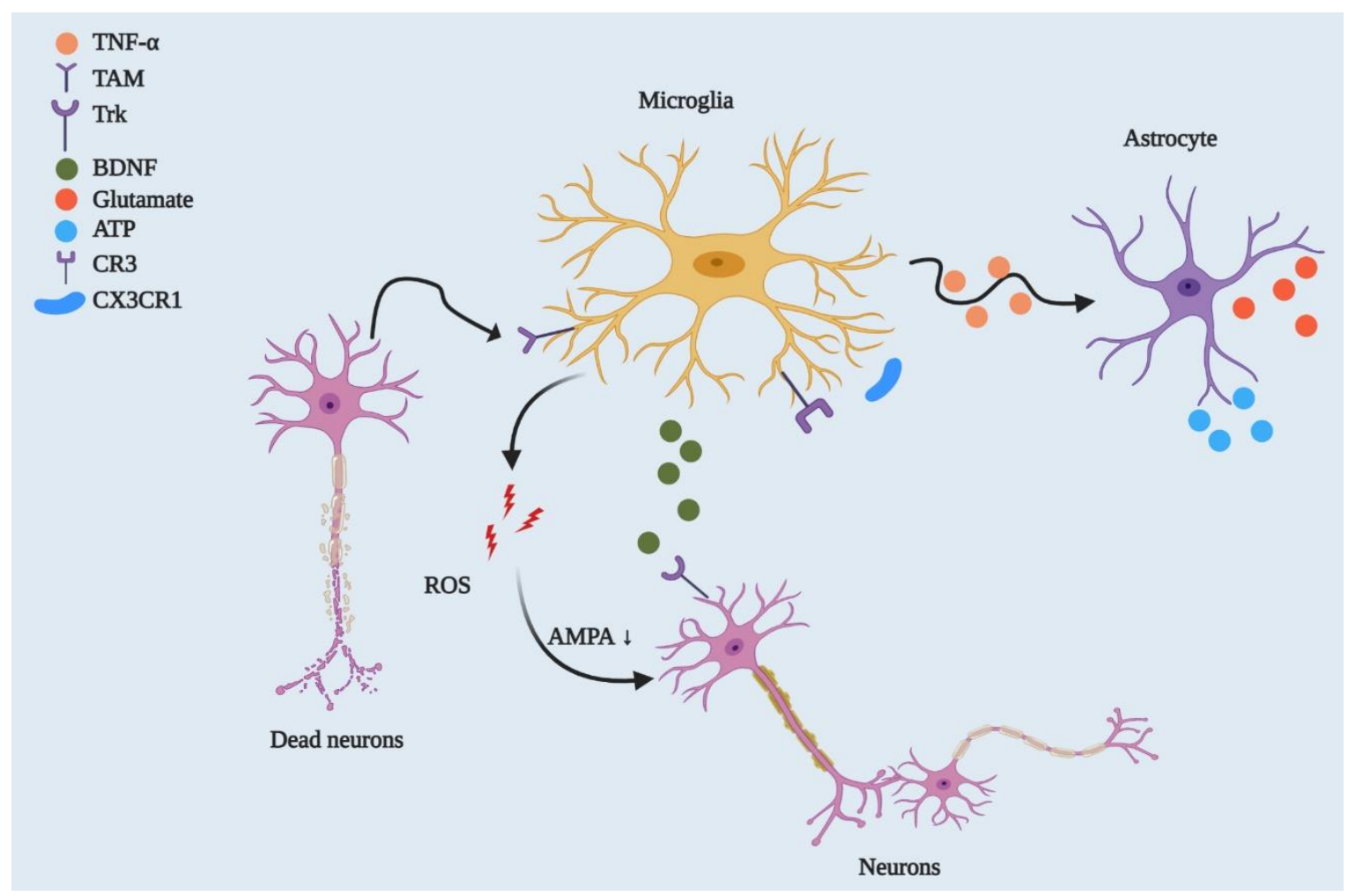

Figure 2. Microglial regulation of neuronal networks and CNS homeostasis. By playing a phagocytic role, microglia engulf dead or degenerated neurons via TAM receptor-mediated recognition of GAS6-opsonised cells. Microglia control synaptic plasticity by downregulating AMPA receptor activity through ROS secretion and by modulating BDNF/Trk receptor pathways. Beyond this, microglia can strip synapses through $C x 3 c r 1-C x 3 c l 1$ interactions and microglial major histocompatibility complex II (MHCII) [32]. They can also affect neuronal circuitry via interacting with astrocytes through the TNF-mediated pathway, which releases glutamate and ATP from astrocytes.

\section{Microglia and Ageing}

Ageing is inevitable, and several structural and functional changes occur in the brain with advanced ageing. For instance, the brain loses a total mass of about 2 to $3 \%$ per decade after the age of 50. This loss of mass with age specifically affects the volume of grey and white matter in the prefrontal, parietal and temporal areas [36-38]. Therefore, an individual gradually loses complex learning abilities and declines in cognitive function $[38,39]$. Several cellular-level changes also occur in ageing brains, such as genomic instability, shortening of telomeres and activation of tumour suppressor genes, protein mutation and accumulation, oxidative stress, reduced autophagy and mild to chronic inflammation. It is imperative to maintain the balance between pro- and anti-inflammatory cytokines. However, a brain undergoing advanced ageing shows an imbalance between these cytokine levels in response to chronic exposure to physical, chemical or biological agents, such as ionic radiation, pollutants and pathogens [40,41]. Studies have shown that chronic exposure to endogenous or exogenous pathogens decreases the anti-inflammatory cytokine IL-10 [42]. In contrast, such exposure also increases inflammatory cytokines such as TNF- $\alpha$ and IL-1 $\beta$ in the CNS [43] and IL-6 in plasma [44]. Additionally, increased systemic inflammation causes neuronal cell death and an imbalance between clearance and production of ROS, severely damaging synaptic plasticity as well (Figures 2 and 3). Many of these alterations in ageing brains include impairment in basal autophagy that begins with cellular stress. Ageing human brain analysis has shown a reduction in autophagy genes, including Atg5, Atg7 and Becn1 [45], and similar downregulation in Atg-proteins has been evident in ageing mouse brains. In contrast, ageing has been found to upregulate mTORC1 $[45,46]$ and accelerated mTOR reduces macroautophagy and promotes aggre- 
gated protein and metabolic disturbances during ageing. These data have been supported by the rapid development of neurodegeneration in Atg5- [47] and Atg7- depleted [48] mice. Microglia, as the first line of host defence, selectively activate autophagy to entrap threatening molecules into autophagosomes and clear them via autophagic degradation. For example, microglial TLR4-induced activation of nuclear factor $\mathrm{KB}$ (NF- $\mathrm{KB}$ ) upregulates p62/SQSTM1 signalling, which degrades misfolded $\alpha$-syn proteins via autophagy and protects against midbrain dopaminergic neuronal loss [49]. Furthermore, ageing-mediated alteration in microglial functions disrupts microglial regulation of autophagy and promotes neuronal loss.

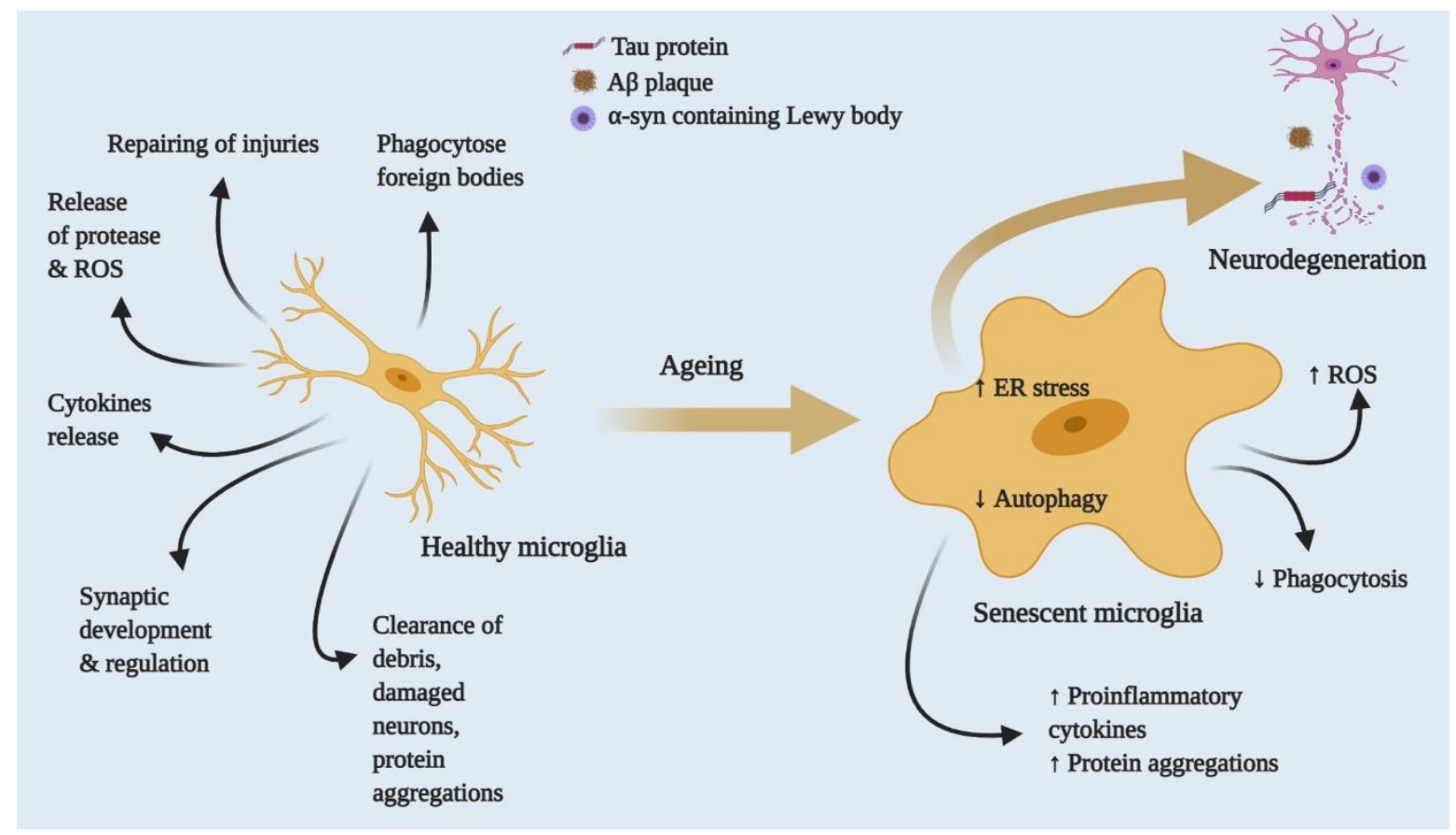

Figure 3. Effects of ageing on healthy to proinflammatory microglia. Healthy microglia regulate the release of cytokines, proteases, ROS and RNS and phagocyte foreign bodies. In addition, they clear cell debris and proteins. With advanced ageing, microglia eventually lose function or functions dysregulated by persistent exposure to foreign bodies or mutations. Increasing microglial ROS production releases proteases and cytokines and slows the autophagic process, leading to aberrant protein aggregation and inflammatory response, neuronal death and neurodegenerative disease.

Ageing has been recognised as a major risk factor for many neurodegenerative disorders. Advanced ageing includes several hallmarks indicating risks of developing neurodegenerative diseases such as Alzheimer's (AD), Parkinson's (PD), Huntington (HD) and frontotemporal lobar (FTD) disease. Furthermore, microglial cells change with ageing, which is one of the major risk factors for age-related development of neurodegeneration. Although neurodegenerative diseases are multifactorial conditions, and their complexity is not yet well understood, there has been scientific agreement on the degenerative diseases and age-related changes they can cause in the neural microenvironment.

Ageing produces the common feature of high heterogeneity in microglia, which is also a common phenotype of different neurodegenerative diseases [39]. Moreover, the pattern of microglial gene expression changes with ageing and neurodegenerative conditions [50]. The major phenotypic changes in ageing microglia are increased soma volume, a retraction in processes and a loss in uniform tissue distribution [51]. Furthermore, microglial activation slows with age, reducing sensing activity and impairing synaptic contact [6]. This process of ageing microglial activation is distinct from classical activation and is referred to as microglial dystrophy; the anomalous activation is more likely to be senescent rather than a classical phenotype [52,53]. Moreover, a new phenotype of microglia has been defined—dark microglia—characterised by condensed electron-dense cytoplasm 
and nucleoplasm, nuclear chromatin remodelling and high levels of synaptic stripping activity and oxidative stress [54,55]. Interestingly, these phenomena have not only been observed in microglial populations associated with chronic stress or diseases such as AD but also in the microglia in normally ageing brains [54]. Although knowledge of these molecular structural changes is still in its infancy, it has already been established that ageing microglia are highly granular and present an uncharacteristic dark appearance in immunohistological preparations. Another phenotypic change in aged microglia is defective lysosomal digestion. This defect largely privileges accumulation of indigestible material composed of lipofuscin and other autofluorescent pigments [56,57]. Therefore, the use of immunofluorescence or flow cytometry has become familiar among researchers to distinguish between normal and aged microglia. Accumulation of such autofluorescent pigments and lipofuscin is believed to be a by-product of impaired disposal mechanisms and purported to have a direct relation to several neurodegenerative diseases, including $\operatorname{AD}[58,59]$.

Microglial changes with age do not follow one specific process but, rather, change throughout one's life; after reaching a certain age, threshold impacts will appear. A transcriptome analysis of the frontal cortex region of post-mortem healthy brains across a wide age range (from young teenagers to people over 80 years old) showed that microglial gene markers assemble into a transcriptional module in a gene co-expression network [60], and this expression pattern negatively correlates with age. Another study revealed that genes that encode microglia surface receptors for neuronal and/or microglial crosstalk are particularly affected. Several brain-expressed transcription factors, including RUNX1, IRF8, PU.1 and TAL1, are the master regulators of age-dependent microglial modulation [39]. This raises the question of how important it is to identify age-dependent genetic modulation in adulthood to understand neurodegenerative disease pathology. Identification at the beginning of genetic changes in middle or late-middle age might correlate several chronic neurodegeneration initiations, and thus may help stall disease progression.

\section{Microglia and Neurodegenerative Diseases: Functional Relation}

\subsection{Alzheimer's Disease}

Alzheimer's disease (AD) is the most prevalent neurodegenerative disorder, which has a characteristic feature of forming $\mathrm{A} \beta$-containing plaques and neurofibrillary tangles (NFTs) containing intracellular hyperphosphorylated tau proteins and leading to neuronal loss [61] (Figures 1 and 3). Microglia play a critical role in the progression and exaggeration of $\mathrm{AD}$, that is, the accumulation of $\mathrm{A} \beta$ triggers microglia to promote tau hyperphosphorylation that eventually forms NFTs, leading to cognitive impairment. Microglia accumulate around senile plaques in $\mathrm{AD}$ brain parenchyma two-to-five times more than in normally functioning brains [62].

Microglia have both direct and indirect relations with AD. Evidence from genomewide association studies (GAWS) has shown variant of Trem 2 mutations increase in risk by 3-4.5 times for developing late-onset $\mathrm{AD}$ [63], which is as high as the association found with ApoE- $\varepsilon 4$ in the AD [64]. Mutations in other microglial genes, such as CR1, HLA-DRB1, CD33, MS4A6A and BIN1, also have a moderate role in AD progression [64]. Although not all AD patients have similar mutant microglial gene(s), because these are core regulator genes of microglial functions, studying their roles in $\mathrm{AD}$ pathogenesis will affect all $\mathrm{AD}$ patients.

A key factor of $\mathrm{AD}$ pathogenesis is $\mathrm{A} \beta$ deposition, which is an equilibrium between $\mathrm{A} \beta$ production and clearance. Small changes in this production-clearance ratio result in abnormal accumulation of $\mathrm{A} \beta$ peptide. Therefore, microglial scavenger receptors (SRs) have an active role in $A \beta$ clearance [65] by phagocytosis and endocytosis $[66,67]$. Microglia can also degrade extracellular $A \beta$ using $A \beta$-degrading enzymes [34,65]. In addition, microglia from the $A \beta$-deposited mouse model showed reduced expression of both $A \beta$ phagocytic receptors and $A \beta$-degrading enzymes [34]. This suggests an active role of microglia in $\mathrm{AD}$ pathogenesis and late-onset $\mathrm{A} \beta$ accumulation. 
However, microglia-A $\beta$ interactions may lead to a loss of synapses [68], increased production of neurotoxic reactive oxygen and nitrogen species (ROS and RNS), activated NLRP3 inflammasomes and increased release of proinflammatory cytokines including TNF $[33,69,70]$. In this way, A $\beta$ interacts with microglial pattern recognition receptors (PRRs), including Toll-like receptors (TLRs), SRs and complement receptor 3 (CR3) [24,71]. Thus, the microglial role in AD is a double-edged sword. For example, microglia sense $A \beta$ peptides and remove these injurious agents before plaques form, whereas chronic interaction of $A \beta$ with microglia reduces this sensing ability, resulting in further amyloid deposition. This reduction of the microglial clearing ability is a part of $A \beta$-induced proinflammatory cytokine production, which also activates NLRP3 and releases ASC, which binds $A \beta$ and promotes further $A \beta$ aggregation and spreading of amyloid pathology [70]. Therefore, while the microglia in early AD progression have a beneficial role, their malfunction will be detrimental to cells as the disease spreads. Furthermore, one study analysed the transcriptome of normal and $\mathrm{A} \beta$-populated microglia and defined diseaseassociated microglia (DAM) [30,72]. Although the difference between DAM and dark microglia is not clear, both have a direct association with $\mathrm{A} \beta$ deposition and exhibit high expressions of $\mathrm{CD} 11 \mathrm{~b}$ and Trem2 [54]. These findings indicated a direct relation between microglial transition from homeostatic to DAM during AD.

\subsection{Parkinson's Disease}

Parkinson's disease (PD) is the second most prevalent neurodegenerative disease, characterised by both motor and non-motor symptoms. Events of PD progression include misfolding of the protein $\alpha$-synuclein and assembly into Lewy bodies and Lewy neurites, which leads to the loss of dopamine neurons in the substantia nigra region of the PD brain [73]. It has become evident from PD patients' substantia nigra that HLA-DRexpressing reactive microglia are abundant [74]. In addition, the oligomeric $\alpha$-synuclein activates microglia through heterodimer TLR1/2 and increases proinflammatory cytokine release [75]. However, the detrimental role of $\alpha$-synuclein might be realised through the phagocytic receptor Axl. To support this hypothesis, a $\alpha$-synuclein mutant $\left(S N C A^{A 53 T}\right)$ mice study was conducted, revealing a high level of Axl receptor expression in spinal cord analysis [26], whereas the deletion of Axl delayed disease onset. Moreover, genetic investigations of sporadic and familial PD have identified leucine-rich repeat kinase 2 (LRRK2) as the most common mutated gene in PD [76]. Furthermore, LRRK2-deficient rats showed no significant dopaminergic neuron loss and reduced myeloid cell activation in substantia nigra; this was shown in rats injected with rAAV2 $\alpha$-synuclein viral particles [77].

Although the exact mechanism that could relate microglia to PD pathogenesis is not yet known, this participation is proposed to be similar to that in $\mathrm{AD}$. As with $\mathrm{A} \beta$ clearance, microglia internalise and degrade $\alpha$-synuclein to clear it. Thus, any anomalies in this process may result in an aggregation of extracellular $\alpha$-synuclein [78]. These findings, although still requiring validation in animal models of $P D$, suggest that both $A D$ and PD share similar pathogenic pathways. This raises the possibility that targeting microglia may also result in the double-edged sword metaphor from earlier, depending on disease progression.

\subsection{Amyotrophic Lateral Sclerosis}

Amyotrophic lateral sclerosis (ALS) is a neurodegenerative disease that causes characteristic features of progressive damage in motor neurons in the cerebral cortex, brainstem and spinal cord, potentially leading to paralysis and death. Although most patients are reported as having sporadic ALS, approximately $10 \%$ of ALS patients have mutations in specific genes, including SOD1, C9orf72, TDP43 and FUS74 [8]. Positron emission tomography (PET) scanning revealed increased cerebral microglia activation in ALS brains [79], and ALS brain autopsies showed that microglia are associated with the expression of proinflammatory cytokine release [80].

Furthermore, transgenic mice overexpressing G93A mutant SOD1 (mSOD1 ${ }^{\mathrm{G} 93 \mathrm{~A}}$ ) developed ALS-like symptoms of progressive motor neuron loss [81-83]. At the early onset 
of disease progression, microglia functions are not affected by mSOD1. Eventually, however, as the disease progresses, microglia aggravate neuronal injury by interacting with motor neurons. In ALS, microglia activate mostly through misfolding and accumulation of mSOD1. In addition, other stressors and ROS-releasing mechanisms also activate microglia and promote microglia-induced proinflammatory cytokine release. In one study, restraining microglial activation by inhibiting NF- $\mathrm{KB}$ signalling substantially reduced motor neuron loss and extended the survival of $\mathrm{mSOD} 1^{\mathrm{G} 93 \mathrm{~A}}$ animals [84].

Microglia change their phenotype with disease progression, accelerating disease onset [85] and exacerbating motor neuron death [86]. However, at early onset, microglia showed neuroprotective tendencies in mSOD1 mice, which increased during the late phase of disease [87]. Microglial activation and neurotoxicity in ALS are cell-autonomous processes and not only include NF- $\mathrm{kB}$-dependent signalling [84], but also partly involve IL-1 $\beta$ [88]. Both intraneuronal and extracellular misfolded mSOD1 are sensed by microglia, and eventually microglia promote superoxide production by deregulating NADPH oxidase [89] and becoming proinflammatory [90]. Therefore, this points to the interrelation of neurodegenerative pathways between ALS, AD and PD, because in all cases where microglia sense exogenous stimuli, they respond to danger in the host and eventually change their phenotype with disease progression [8].

The expansion of hexanucleotide repeating in noncoding regions of C9orf72 gene have displayed pathologic features of ALS in mice but have not shown behavioural abnormalities or neurodegeneration [91,92]. On the other hand, a lack of C9orf72 causes lysosomal accumulation and increases the microglial immune response and proinflammatory activity in the host [91]. Moreover, C9orf72 is required for maintenance of myeloid cells' normal functioning. Although these findings seem to contradict each other, the mystery of $C 9$ orf 72 in normal microglial function has been uncovered, at least in part. Altering C9orf 72 also changes microglia-mediated misfolded protein clearance by modulating phagosometo-lysosome maturation, suggesting that this subset may have a potential role in ALS. Therefore, future functional studies with microglia from C9orf72 ALS patient may clarify the complexity.

Mice expressing inducible human TDP-43 (hTDP-43) showed progressive motor neuron loss, but suppressing hTDP-43 allowed microglia to clear existing hTDP-43 [93]. Interestingly, blocking microgliosis at the early recovery phase by using CSF1R and c-Kit inhibitors diminished the mice's ability to completely retain motor functions, suggesting that microglia play a neuroprotective role [93]. In contrast, conditional deletion of TDP-43 in microglia increased their phagocytic functions and enhanced synaptic loss [94]. Thus, future studies should further investigate the link between TDP-43, microglia and ALS pathogenesis, which would help ALS patients with TDP-43 mutations by minimising dysregulation of microglial phagocytic function. This paper proposes that targeting microglia for intervening ALS should target several mutations that are associated with microglial host defence functions including $m S O D 1$ (ROS production), C9orf72 (cytokines), and C9orf72 and TDP43 (phagocytosis). Thus, targeting microglia randomly in ALS to rejuvenate associated host defence functions may not be a useful therapeutic strategy but tailoring to a specific pathway(s) could affect potentially.

\subsection{Multiple Sclerosis}

In young adults, multiple sclerosis (MS) is the most frequent neuroautoimmune disorder and is associated with severe physical nontraumatic disability. Well-defined neuroinflammatory demyelinating lesions and neuronal loss are the characteristic hallmarks of MS. Patients of this disorder begin by developing demyelinated plaques in both white and grey matter, and ongoing disease progression leads to brain atrophy and neurodegeneration. Because neuroinflammation has been evident in all stages of MS, it is proposed that the presence or absence of microglia play at least a part in inflammatory CNS of MS patients $[95,96]$. However, the challenge is correct distinction of resident microglia and 
other CNS macrophages, along with infiltrating monocyte-derived macrophages during progressive MS because all share the same surface markers and functions.

Microglia's role in MS is unclear; they may be detrimental or beneficial. At the early onset of this disease, microglia promote axonal regeneration, clear myelin debris and release neurotrophic factors, indicating their protective role in MS [97]. However, a study of mice with experimental autoimmune encephalitis (EAE), an animal MS model, showed enhanced release of proteases, proinflammatory cytokines, ROS and RNS from microglia and recruitment of reactive $\mathrm{T}$ lymphocytes. Thereafter, this leads to neurotoxicity, whereas deletion of the transforming growth factor (TGF)- $\beta$-activated kinase 1 in the microglia of the EAE mouse model displayed reduced CNS inflammation. At the same time, axonal and myelin damage were reduced by the cell-autonomous inhibition of the NF- $\mathrm{KB}$, JNK and ERK1/2 pathways [21], indicating that microglia may aggravate tissue injury in EAE. These results suggested that microglia actively participate at different stages of MS progression, and their role eventually changes with advancement of disease. Furthermore, it is possible that microglial function alteration is associated with specific lesions in MS, including changes in debris clearance and the neuroprotective response.

\subsection{Huntington's Disease}

Huntington's disease (HD) is an autosomal dominant disease, featuring progressive atrophy of the striatum and cortex $[98,99]$. An immunohistochemical analysis of a human HD brain showed reactive microglia present in the cortex, neostriatum and globus pallidum $[100,101]$. Active microglia in the striatum and cortex were also found to be related to the onset of neuronal loss [101]. In addition, a microscopic analysis of an HD model showed intranuclear inclusions containing huntingtin (HTT) protein and neurodegeneration of medium-size spiny, encephalin-containing inhibitory neurons [99]. In this condition, mutation in the HTT (mHTT) protein stretches the trinucleotide CAG and translates into polyglutamine in HTT protein sequencing, leading to HD [99].

However, microglia express HTT mRNA at a relatively high level [24], and the presence of proinflammatory microglia is correlated with a higher probability of developing HD within five years [102]. Therefore, HD severity is dependent on proinflammatory microglial onset in HD patients [101,103]. Furthermore, progressive HD changes microglia function and the genomic profile. Increased mHTT expression has been found to be linked to increases in proinflammatory genes in HD patients and in the mouse model [104], promoting myeloid linage-determining factors PU.1 and CCAAT/enhancer-binding protein (C/EBP)$\alpha, \beta$. This increase in transcriptional factors is correlated with the higher expression of IL-6 and TNF, and this change solely occurs in microglia [104]. Because microglia have a role as innate defensive units in their host, mHTT microglia increased several genes that sense their milieu, including Tlr2, Cd14, Fcgr1, Clec4d, Adora3, Tlr9 and Tnfrsf1b [24,104], suggesting increase in capacity to sense extracellular stimuli. In response, the system upregulates IL-6 and TNF mRNA [104], suggesting that microglial responses have a host defence function against mHTT invasion, thereby aggravating neurodegeneration.

\subsection{Frontotemporal Dementia}

Frontotemporal dementia (FTD) is a progressive neuronal atrophy characterised by rapid neuronal loss in the frontal and temporal cortices [105]. Immunohistochemical analysis of FTD patients has shown the presence of aggregated TDP-43 in the cytoplasmic inclusions [94]. However, PET imaging of FTD patients has reported reactive microglia correlated with increased expression of proinflammatory cytokines TNF and IL- $1 \beta$ in the CSF [94]. Moreover, recent research documented that mutations in the Grn gene, encoded for the glycoprotein progranulin, lead to FTD. In addition, progranulin is mainly expressed by neurons and microglia in the CNS [106]. In pathological conditions, microglia upregulate progranulin; however, it is assumed that progranulin deficiency might impair autophagy and lead to FTD progression [106]. In support of this, progranulin deletion in mice showed increased microgliosis [107]. Based on these results, this study proposed that microglia 
have a potential role in FTD, and, as in other neurodegenerative diseases, they should be evaluated by genomic study in the future.

\subsection{Prion Disease}

Prion diseases include spongiform encephalopathies and are due to the gradual aggregation of the prion protein $\mathrm{PrP}^{\mathrm{Sc}}$ [7]. In this vein, $\mathrm{PrP}^{\mathrm{Sc}}$ can transmit itself into new hosts as an exogenous seed that can cause protein misfolding and aggregation, as well as aggravate the disease in the absence of microbial agents, viruses or inflammation. This feature is referred to as the prion paradigm and has been evident in cases of other neurodegenerative diseases, including AD, PD, ALS and FTD [7,108]. Prion-related neurodegeneration includes increased neuronal loss and proinflammatory microglia. Microglia and other CNS macrophages phagocytose $\mathrm{PrP}^{\mathrm{Sc}}$ approximately 60 days earlier after sensing infection [109], but their depletion increases prion infection susceptibility [110], suggesting that microglia play a major role in controlling prion disease. The double-edged sword metaphor applies here as well for microglia because they produce ROS in response to the PrP106-126 fragment and promote PrP-induced neurotoxicity. Suppressing the superoxide-producing enzymes produced protective results from PrP-induced toxicity in mice, further suggesting that microglia mediate prion neurodegeneration [111].

Although it is unclear whether or not microglial proinflammatory releases affect prion disease progression, several proinflammatory cytokines-IL-1 $\beta$, IL-6, inducible nitric oxide synthase (iNOS), NF- $\mathrm{KB}$, cyclophilin A, matrix metalloproteinases and NLRP3 inflammasome components-have been upregulated in prion disease microglia $[112,113]$. It has also been shown that prion infection affects microglial sensing and housekeeping ability through the disruption of the Cx3cr1-fractalkine pathway [114]. Prion protein PrPSc impairs microglial ability to phagocytose aberrant proteins, including $\operatorname{PrP}^{\mathrm{Sc}}$ and apoptotic debris or cells. In addition, this impairment promotes the microglial proinflammatory mediator's production, which dysregulates host defence [115]. Microglial function regarding $\mathrm{PrP}^{\mathrm{Sc}}$ is SR- and TLR-mediated in an Src-kinase-dependent manner [116,117], which suggests that microglia might initially engage in $\mathrm{PrP}^{\mathrm{Sc}}$ clearance, but their consistent malfunctions and activation in another example impair the host-defensive response. Thus, normal microglial functions result in neurotoxic action and subsequently aid in disease progression.

Thus far, two common themes for microglia involvement in different neurodegenerative diseases have emerged. First, microglia perform their regular sentinel function after sensing the aberrant or misfolded proteins such as $\mathrm{A} \beta$, aggregated $\alpha$-synuclein, oxidised or mutant SOD1, or $\operatorname{PrP}^{\mathrm{Sc}}$ (Figure 1). Next, they attempt to clear those toxic stimuli via SRs and/or other PRRs as their host-defence function. However, persistent production of aberrant proteins reduces microglial host-defence regulatory functions and dysregulates microglial immune checkpoints that keep microglia-induced inflammation in control, such as the Cx3cr1 or progranulin pathways. Thus, normal microglia are led into a proinflammatory state and a further response in the host defence through exaggerated neuroinflammation and neurodegeneration. Second, some neurodegenerative diseases cause self-autonomous actions; mutations in specific genes, such as Trem2, HTT and TDP43, and dysregulate host abilities of sensing, housekeeping and defence. In this way, microglial actions initiate or exaggerate neurotoxicity and neurodegeneration.

\section{Microglia as a Therapeutic Possibility in Neurodegenerative Diseases}

Microglia play vital roles at different brain development phases. With age or due to aberrant endogenous or exogenous stimuli, they begin losing their normal physiological functions. Thus, homeostasis in CNS microglia is necessary to disrupt neurodegenerative disease pathology and progression. In addition, identification of critical microglial markers is important to find new therapeutic strategies. Initial studies have suggested an M1 and M2 activation paradigm, in which M1 activation promotes inflammatory cytokines, and M2 activation promotes neurotrophic factor release. However, advanced studies have found that this paradigm does not fit during neurodegeneration. That is, M1/M2 activation does 
not always function as expected. For instance, in regular cases, M1 activation produces neurotoxicity via proinflammatory release, whereas in some cases, this activation promotes axonal regeneration [118]. An AD model study showed that M1 activation promotes A $\beta$ plaque clearance, and, in contrast, M2 activation may ease amyloid spread [119].

Microglia are emerging as a cell type used to understand neurodegenerative diseases, but the major challenge is studying human microglia in vitro. For an in vitro neurological disease model study, microglial cells could possibly be developed by differentiating iPSCs or monocytes [120,121], which has recently been demonstrated. In addition, authors have shown that human microglial-like cells (iMGLs) have phenotypic similarity to in vivo microglia, such as through inflammatory cytokine release or CNS substrate phagocytosis. On the other hand, human monocyte-derived, microglia-like (MDMi) cells have not only presented with microglia phenotype and functions but have also presented with altered expression of gene loci related to neurodegenerative diseases such as $\mathrm{AD}, \mathrm{PD}$ and MS. These two in vitro microglial cell models could beneficiate therapeutics screening in vitro for neurodegenerative diseases. In addition, genetic defects in microglia could be edited by replacing allogenic or autologous stem cells or monocytes through bone marrow transplantation. Although the latter has not been successfully established for all neurological diseases-though it has for X-linked adrenoleukodystrophy — a recent study showed that brain-engrafted bone marrow derived microglia after a long time in AD mice [122,123]. It has been suggested that peripheral myeloid cells constitute a heterogeneous cell population that is more effective at clearing $\mathrm{A} \beta$ plaque than $\mathrm{CNS}$ resident microglia. Extrapolating this therapy with additional triggering could bring success or could be useful for studying other neurological diseases.

Microglial phagocytosis could be another option, but therapeutic agents that target microglial phagocytosis can have both beneficial and detrimental effects-another doubleedged sword in neurodegeneration. Microglial phagocytosis opsonises misfolded protein plaques, including $A \beta$, via the Fc receptor to help antibodies that target misfolded proteins $[7,124,125]$. In the same way, defective microglia activation in Trem2-deficient mice showed a lack of effectiveness toward the anti-A $\beta$ antibodies [126]. Several antibodies currently used in autoimmune diseases may be beneficial in neurodegenerative diseases as well because they target specific proinflammatory cytokines, such as IL-6 and IL-1, or their receptors. Compounds targeting CSF1R can affect proinflammatory microglia activation in $\mathrm{AD}[127,128]$ and reduce microglia-induced inflammation and/or neuronal death [129] in neurodegenerative diseases. In the same vein, IL-34 and CSF1, ligands of CSF1R, may provide neuroprotection and promote neuronal cell survival shown in neurodegenerative models by activating CSF1R in neuron populations but not in microglia [130].

In addition, bexarotene-induced Trem 2 expression in microglia is, at least in part, mediated by ApoE/Trem2 signalling activation [131]. Thus, developing anti-ApoE antibodies in carriers of the ApoE4 allele may help to prevent amyloid deposition and its consequences [132]. Moreover, neuronal autophagy has been shown to be useful in neurodegenerative diseases for clearing misfolded proteins and reducing inflammatory cytokines [133]. However, very little is known about the role of microglia in autophagy. In one study, loss-of-function mutations of TBK1 affected autophagy in myeloid cells and increased susceptibility to ALS [134]. Beyond this, microglial autophagy facilitates A $\beta$ clearance and reduces NLRP3 inflammasome activation [135]. Therefore, further study of autophagy in microglia may enhance the understanding of whether drugs activating autophagy have beneficial or detrimental impacts on neurodegenerative diseases.

\section{Conclusions}

Microglial biology has gained substantial attention in recent decades. Several advancements have been introduced, including microglial gene expression checks, longevity analysis in a single cell in the neurodegenerative disease model, pathways that regulate their responses to neuronal injury, pathways that check microglial inflammatory responses and pathways that promote injurious stimuli clearance. In addition, advanced research 
has shown how peripheral influences from the gut microbiome can alter such injuries. However, substantial knowledge gaps exist that slow the therapy-finding process through the microglial regulated pathway. One major limitation in this process is a reliable disease model. More reliable cellular in vitro disease models and the addition of new technologies for in vivo modelling for better imaging and analysis could strengthen understanding of microglial involvement in neurodegeneration. Furthermore, analysis of the transcriptomes and epigenetic profiles in various diseases shows that it is essential to understand the relevance of ageing and disease progression in relation to the alteration in these profiles at the single-cell level and to thereafter correlate such changes with microglial behaviour. Finally, these steps could bring about a crucial breakthrough in microglia-mediated therapeutic intervention in neurodegenerative diseases.

Author Contributions: S.A., D.-K.C. and I.-S.K. conceptualised and designed the study; D.-K.C. also supervised and corresponded. S.A. and M.E.H. collected and reviewed the literature; S.A. wrote the manuscript and conceptualised figures. M.E.H. helped in revising the paper. All authors have read and agreed to the published version of the manuscript.

Funding: Basic Science Research Program through the National Research Foundation of Korea (NRF) funded by the Ministry of Education, Science, and Technology (NRF-2020R1A2B5B02002032).

Institutional Review Board Statement: Not applicable.

Informed Consent Statement: Not applicable.

Data Availability Statement: Not applicable.

Conflicts of Interest: All authors declare no conflict of interest.

\begin{abstract}
Abbreviations
ApoE, apolipoprotein E; APP, amyloid precursor protein; AD, Alzheimer disease; ALS, amyotrophic lateral sclerosis; PD, Parkinson disease; PS, presenilin; PRR, pattern-recognition receptor; TLR, Toll-like receptor; BDNF, brain-derived neurotrophic factor; TAM, Tyro3 and Axl and Mertk receptors; GAS6, growth arrest-specific 6; ROS, reactive oxygen species; RNS, reactive nitrogen species; AMPA, $\alpha$-amino-3-hydroxy-5-methyl-4-isoxazolepropionic acid receptor; Trk, neurotrophic receptor tyrosine kinase; MMPs, matrix metalloproteases; $\mathrm{A} \beta \mathrm{DE}, \mathrm{A} \beta$-degrading enzymes.
\end{abstract}

\title{
References
}

1. Crotti, A.; Ransohoff, R.M. Microglial Physiology and Pathophysiology: Insights from Genome-wide Transcriptional Profiling. Immunity 2016, 44, 505-515. [CrossRef] [PubMed]

2. Ginhoux, F.; Greter, M.; Leboeuf, M.; Nandi, S.; See, P.; Gokhan, S.; Mehler, M.F.; Conway, S.J.; Ng, L.G.; Stanley, E.R.; et al. Fate mapping analysis reveals that adult microglia derive from primitive macrophages. Science 2010, 330, 841-845. [CrossRef] [PubMed]

3. Sheng, J.; Ruedl, C.; Karjalainen, K. Most Tissue-Resident Macrophages Except Microglia Are Derived from Fetal Hematopoietic Stem Cells. Immunity 2015, 43, 382-393. [CrossRef] [PubMed]

4. Hashimoto, D.; Chow, A.; Noizat, C.; Teo, P.; Beasley, M.B.; Leboeuf, M.; Becker, C.D.; See, P.; Price, J.; Lucas, D.; et al. Tissueresident macrophages self-maintain locally throughout adult life with minimal contribution from circulating monocytes. Immunity 2013, 38, 792-804. [CrossRef] [PubMed]

5. Pelvig, D.P.; Pakkenberg, H.; Stark, A.K.; Pakkenberg, B. Neocortical glial cell numbers in human brains. Neurobiol. Aging 2008, 29, 1754-1762. [CrossRef]

6. Hefendehl, J.K.; Neher, J.J.; Sühs, R.B.; Kohsaka, S.; Skodras, A.; Jucker, M. Homeostatic and injury-induced microglia behavior in the aging brain. Aging Cell 2014, 13, 60-69. [CrossRef]

7. Colonna, M.; Butovsky, O. Microglia Function in the Central Nervous System during Health and Neurodegeneration. Annu. Rev. Immunol. 2017, 35, 441-468. [CrossRef]

8. Hickman, S.; Izzy, S.; Sen, P.; Morsett, L.; El Khoury, J. Microglia in neurodegeneration. Nat. Neurosci. 2018, 21, 1359-1369. [CrossRef]

9. Gómez-Nicola, D.; Fransen, N.L.; Suzzi, S.; Perry, V.H. Regulation of microglial proliferation during chronic neurodegeneration. J. Neurosci. Off. J. Soc. Neurosci. 2013, 33, 2481-2493. [CrossRef] 
10. Füger, P.; Hefendehl, J.K.; Veeraraghavalu, K.; Wendeln, A.C.; Schlosser, C.; Obermüller, U.; Wegenast-Braun, B.M.; Neher, J.J.; Martus, P.; Kohsaka, S.; et al. Microglia turnover with aging and in an Alzheimer's model via long-term in vivo single-cell imaging. Nat. Neurosci. 2017, 20, 1371-1376. [CrossRef]

11. Lawson, L.J.; Perry, V.H.; Gordon, S. Turnover of resident microglia in the normal adult mouse brain. Neuroscience 1992, 48 , 405-415. [CrossRef]

12. Askew, K.; Li, K.; Olmos-Alonso, A.; Garcia-Moreno, F.; Liang, Y.; Richardson, P.; Tipton, T.; Chapman, M.A.; Riecken, K.; Beccari, S.; et al. Coupled Proliferation and Apoptosis Maintain the Rapid Turnover of Microglia in the Adult Brain. Cell Rep. 2017, 18, 391-405. [CrossRef] [PubMed]

13. Tay, T.L.; Mai, D.; Dautzenberg, J.; Fernandez-Klett, F.; Lin, G.; Datta, M.; Drougard, A.; Stempfl, T.; Ardura-Fabregat, A.; Staszewski, O; i et al. A new fate mapping system reveals context-dependent random or clonal expansion of microglia. Nat. Neurosci. 2017, 20, 793-803. [CrossRef] [PubMed]

14. Nowakowski, R.S.; Hayes, N.L. New neurons: Extraordinary evidence or extraordinary conclusion? Science 2000, $288,771$. [CrossRef]

15. Rakic, P. Neurogenesis in adult primates. Prog. Brain Res. 2002, 138, 3-14. [CrossRef]

16. Knuesel, I.; Chicha, L.; Britschgi, M.; Schobel, S.A.; Bodmer, M.; Hellings, J.A.; Toovey, S.; Prinssen, E.P. Maternal immune activation and abnormal brain development across CNS disorders. Nat. Rev. Neurol. 2014, 10, 643-660. [CrossRef]

17. Perry, V.H.; Holmes, C. Microglial priming in neurodegenerative disease. Nat. Rev. Neurol. 2014, 10, 217-224. [CrossRef]

18. Streit, W.J.; Xue, Q.S.; Tischer, J.; Bechmann, I. Microglial pathology. Acta Neuropathol. Commun. 2014, 2, 142. [CrossRef]

19. Lawson, L.J.; Perry, V.H.; Dri, P.; Gordon, S. Heterogeneity in the distribution and morphology of microglia in the normal adult mouse brain. Neuroscience 1990, 39, 151-170. [CrossRef]

20. El Khoury, J. Neurodegeneration and the neuroimmune system. Nat. Med. 2010, 16, 1369-1370. [CrossRef]

21. Ransohoff, R.M.; El Khoury, J. Microglia in Health and Disease. Cold Spring Harb. Perspect. Biol. 2015, 8, a020560. [CrossRef]

22. Kierdorf, K.; Erny, D.; Goldmann, T.; Sander, V.; Schulz, C.; Perdiguero, E.G.; Wieghofer, P.; Heinrich, A.; Riemke, P.; Hölscher, C.; et al. Microglia emerge from erythromyeloid precursors via Pu.1- and Irf8-dependent pathways. Nat. Neurosci. 2013, 16, 273-280. [CrossRef]

23. Wang, Y.; Szretter, K.J.; Vermi, W.; Gilfillan, S.; Rossini, C.; Cella, M.; Barrow, A.D.; Diamond, M.S.; Colonna, M. IL-34 is a tissue-restricted ligand of CSF1R required for the development of Langerhans cells and microglia. Nat. Immunol. 2012, 13, 753-760. [CrossRef] [PubMed]

24. Hickman, S.E.; Kingery, N.D.; Ohsumi, T.K.; Borowsky, M.L.; Wang, L.C.; Means, T.K.; El Khoury, J. The microglial sensome revealed by direct RNA sequencing. Nat. Neurosci. 2013, 16, 1896-1905. [CrossRef] [PubMed]

25. Haynes, S.E.; Hollopeter, G.; Yang, G.; Kurpius, D.; Dailey, M.E.; Gan, W.B.; Julius, D. The P2Y12 receptor regulates microglial activation by extracellular nucleotides. Nat. Neurosci. 2006, 9, 1512-1519. [CrossRef] [PubMed]

26. Fourgeaud, L.; Través, P.G.; Tufail, Y.; Leal-Bailey, H.; Lew, E.D.; Burrola, P.G.; Callaway, P.; Zagórska, A.; Rothlin, C.V.; Nimmerjahn, A.; et al. TAM receptors regulate multiple features of microglial physiology. Nature 2016, 532, 240-244. [CrossRef] [PubMed]

27. Vasek, M.J.; Garber, C.; Dorsey, D.; Durrant, D.M.; Bollman, B.; Soung, A.; Yu, J.; Perez-Torres, C.; Frouin, A.; Wilton, D.K.; et al. A complement-microglial axis drives synapse loss during virus-induced memory impairment. Nature 2016, 534, 538-543. [CrossRef]

28. Lui, H.; Zhang, J.; Makinson, S.R.; Cahill, M.K.; Kelley, K.W.; Huang, H.Y.; Shang, Y.; Oldham, M.C.; Martens, L.H.; Gao, F.; et al. Progranulin Deficiency Promotes Circuit-Specific Synaptic Pruning by Microglia via Complement Activation. Cell 2016, 165, 921-935. [CrossRef]

29. Fuhrmann, M.; Bittner, T.; Jung, C.K.; Burgold, S.; Page, R.M.; Mitteregger, G.; Haass, C.; LaFerla, F.M.; Kretzschmar, H.; Herms, J. Microglial Cx3cr1 knockout prevents neuron loss in a mouse model of Alzheimer's disease. Nat. Neurosci. 2010, 13, 411-413. [CrossRef]

30. Krasemann, S.; Madore, C.; Cialic, R.; Baufeld, C.; Calcagno, N.; El Fatimy, R.; Beckers, L.; O'Loughlin, E.; Xu, Y.; Fanek, Z.; et al. The TREM2-APOE Pathway Drives the Transcriptional Phenotype of Dysfunctional Microglia in Neurodegenerative Diseases. Immunity 2017, 47, 566-581. [CrossRef]

31. Healy, L.M.; Perron, G.; Won, S.Y.; Michell-Robinson, M.A.; Rezk, A.; Ludwin, S.K.; Moore, C.S.; Hall, J.A.; Bar-Or, A.; Antel, J.P. MerTK Is a Functional Regulator of Myelin Phagocytosis by Human Myeloid Cells. J. Immunol. 2016, 196, 3375-3384. [CrossRef]

32. Pasciuto, E.; Burton, O.T.; Roca, C.P.; Lagou, V.; Rajan, W.D.; Theys, T.; Mancuso, R.; Tito, R.Y.; Kouser, L.; Callaerts-Vegh, Z.; et al. Microglia Require CD4 T Cells to Complete the Fetal-to-Adult Transition. Cell 2020, 182, 625-640. [CrossRef]

33. El Khoury, J.B.; Moore, K.J.; Means, T.K.; Leung, J.; Terada, K.; Toft, M.; Freeman, M.W.; Luster, A.D. CD36 mediates the innate host response to beta-amyloid. J. Exp. Med. 2003, 197, 1657-1666. [CrossRef]

34. Hickman, S.E.; Allison, E.K.; El Khoury, J. Microglial dysfunction and defective beta-amyloid clearance pathways in aging Alzheimer's disease mice. J. Neurosci. Off. J. Soc. Neurosci. 2008, 28, 8354-8360. [CrossRef]

35. El Khoury, J.; Toft, M.; Hickman, S.E.; Means, T.K.; Terada, K.; Geula, C.; Luster, A.D. Ccr2 deficiency impairs microglial accumulation and accelerates progression of Alzheimer-like disease. Nat. Med. 2007, 13, 432-438. [CrossRef]

36. Ge, Y.; Grossman, R.I.; Babb, J.S.; Rabin, M.L.; Mannon, L.J.; Kolson, D.L. Age-related total gray matter and white matter changes in normal adult brain. Part I: Volumetric MR imaging analysis. Ajnr. Am. J. Neuroradiol. 2002, 23, 1327-1333. 
37. Sowell, E.R.; Peterson, B.S.; Thompson, P.M.; Welcome, S.E.; Henkenius, A.L.; Toga, A.W. Mapping cortical change across the human life span. Nat. Neurosci. 2003, 6, 309-315. [CrossRef]

38. Salat, D.H.; Buckner, R.L.; Snyder, A.Z.; Greve, D.N.; Desikan, R.S.; Busa, E.; Morris, J.C.; Dale, A.M.; Fischl, B. Thinning of the cerebral cortex in aging. Cerebral Cortex 2004, 14, 721-730. [CrossRef]

39. Von Bernhardi, R.; Eugenín-von Bernhardi, L.; Eugenín, J. Microglial cell dysregulation in brain aging and neurodegeneration. Front. Aging Neurosci. 2015, 7, 124. [CrossRef]

40. Dröge, W.; Schipper, H.M. Oxidative stress and aberrant signaling in aging and cognitive decline. Aging Cell 2007, 6, 361-370. [CrossRef]

41. Vijg, J.; Campisi, J. Puzzles, promises and a cure for ageing. Nature 2008, 454, 1065-1071. [CrossRef] [PubMed]

42. Zhang, B.; Bailey, W.M.; Braun, K.J.; Gensel, J.C. Age decreases macrophage IL-10 expression: Implications for functional recovery and tissue repair in spinal cord injury. Exp. Neurol. 2015, 273, 83-91. [CrossRef] [PubMed]

43. Lukiw, W.J. Gene expression profiling in fetal, aged, and Alzheimer hippocampus: A continuum of stress-related signaling. Neurochem. Res. 2004, 29, 1287-1297. [CrossRef] [PubMed]

44. Godbout, J.P.; Chen, J.; Abraham, J.; Richwine, A.F.; Berg, B.M.; Kelley, K.W.; Johnson, R.W. Exaggerated neuroinflammation and sickness behavior in aged mice following activation of the peripheral innate immune system. Faseb J. Off. Publ. Fed. Am. Soc. Exp. Biol. 2005, 19, 1329-1331. [CrossRef]

45. Ott, C.; König, J.; Höhn, A.; Jung, T.; Grune, T. Macroautophagy is impaired in old murine brain tissue as well as in senescent human fibroblasts. Redox Biol. 2016, 10, 266-273. [CrossRef]

46. Plaza-Zabala, A.; Sierra-Torre, V.; Sierra, A. Autophagy and Microglia: Novel Partners in Neurodegeneration and Aging. Int. J. Mol. Sci. 2017, 18, 598. [CrossRef]

47. Hara, T.; Nakamura, K.; Matsui, M.; Yamamoto, A.; Nakahara, Y.; Suzuki-Migishima, R.; Yokoyama, M.; Mishima, K.; Saito, I.; Okano, H.; et al. Suppression of basal autophagy in neural cells causes neurodegenerative disease in mice. Nature 2006, 441, 885-889. [CrossRef]

48. Komatsu, M.; Waguri, S.; Chiba, T.; Murata, S.; Iwata, J.; Tanida, I.; Ueno, T.; Koike, M.; Uchiyama, Y.; Kominami, E.; et al. Loss of autophagy in the central nervous system causes neurodegeneration in mice. Nature 2006, 441, 880-884. [CrossRef]

49. Choi, I.; Zhang, Y.; Seegobin, S.P.; Pruvost, M.; Wang, Q.; Purtell, K.; Zhang, B.; Yue, Z. Microglia clear neuron-released $\alpha$-synuclein via selective autophagy and prevent neurodegeneration. Nat. Commun. 2020, 11, 1386. [CrossRef]

50. Holtman, I.R.; Raj, D.D.; Miller, J.A.; Schaafsma, W.; Yin, Z.; Brouwer, N.; Wes, P.D.; Möller, T.; Orre, M.; Kamphuis, W.; et al. Induction of a common microglia gene expression signature by aging and neurodegenerative conditions: A co-expression meta-analysis. Acta Neuropathol. Commun. 2015, 3, 31. [CrossRef]

51. Wong, W.T. Microglial aging in the healthy CNS: Phenotypes, drivers, and rejuvenation. Front. Cell. Neurosci. 2013, 7, 22. [CrossRef]

52. Streit, W.J.; Braak, H.; Xue, Q.S.; Bechmann, I. Dystrophic (senescent) rather than activated microglial cells are associated with tau pathology and likely precede neurodegeneration in Alzheimer's disease. Acta Neuropathol. 2009, 118, 475-485. [CrossRef] [PubMed]

53. Streit, W.J.; Sammons, N.W.; Kuhns, A.J.; Sparks, D.L. Dystrophic microglia in the aging human brain. Glia 2004, 45, $208-212$. [CrossRef] [PubMed]

54. Bisht, K.; Sharma, K.P.; Lecours, C.; Sánchez, M.G.; El Hajj, H.; Milior, G.; Olmos-Alonso, A.; Gómez-Nicola, D.; Luheshi, G.; Vallières, L.; et al. Dark microglia: A new phenotype predominantly associated with pathological states. Glia 2016, 64, 826-839. [CrossRef] [PubMed]

55. Koellhoffer, E.C.; McCullough, L.D.; Ritzel, R.M. Old Maids: Aging and Its Impact on Microglia Function. Int. J. Mol. Sci. 2017, 18, 769. [CrossRef] [PubMed]

56. Nakanishi, H.; Wu, Z. Microglia-aging: Roles of microglial lysosome- and mitochondria-derived reactive oxygen species in brain aging. Behav. Brain Res. 2009, 201, 1-7. [CrossRef] [PubMed]

57. Mrak, R.E.; Griffin, S.T.; Graham, D.I. Aging-associated changes in human brain. J. Neuropathol. Exp. Neurol. 1997, 56, 1269-1275. [CrossRef]

58. Gray, D.A.; Woulfe, J. Lipofuscin and aging: A matter of toxic waste. Sci. Aging Knowl. Environ. Sage Ke 2005, 2005, re1. [CrossRef]

59. Ahmed, Z.; Sheng, H.; Xu, Y.F.; Lin, W.L.; Innes, A.E.; Gass, J.; Yu, X.; Wuertzer, C.A.; Hou, H.; Chiba, S.; et al. Accelerated lipofuscinosis and ubiquitination in granulin knockout mice suggest a role for progranulin in successful aging. Am. J. Pathol. 2010, 177, 311-324. [CrossRef]

60. Wehrspaun, C.C.; Haerty, W.; Ponting, C.P. Microglia recapitulate a hematopoietic master regulator network in the aging human frontal cortex. Neurobiol. Aging 2015, 36, 2443.e9-2443.e20. [CrossRef]

61. Selkoe, D.J.; Hardy, J. The amyloid hypothesis of Alzheimer's disease at 25 years. Embo Mol. Med. 2016, 8, 595-608. [CrossRef]

62. Frautschy, S.A.; Yang, F.; Irrizarry, M.; Hyman, B.; Saido, T.C.; Hsiao, K.; Cole, G.M. Microglial response to amyloid plaques in APPsw transgenic mice. Am. J. Pathol. 1998, 152, 307-317.

63. Jonsson, T.; Stefansson, H.; Steinberg, S.; Jonsdottir, I.; Jonsson, P.V.; Snaedal, J.; Bjornsson, S.; Huttenlocher, J.; Levey, A.I.; Lah, J.J.; et al. Variant of TREM2 associated with the risk of Alzheimer's disease. New Engl. J. Med. 2013, 368, 107-116. [CrossRef] [PubMed] 
64. Lambert, J.C.; Ibrahim-Verbaas, C.A.; Harold, D.; Naj, A.C.; Sims, R.; Bellenguez, C.; DeStafano, A.L.; Bis, J.C.; Beecham, G.W.; Grenier-Boley, B.; et al. Meta-analysis of 74,046 individuals identifies 11 new susceptibility loci for Alzheimer's disease. Nat. Genet. 2013, 45, 1452-1458. [CrossRef] [PubMed]

65. Yoon, S.S.; Jo, S.A. Mechanisms of Amyloid- $\beta$ Peptide Clearance: Potential Therapeutic Targets for Alzheimer's Disease. Biomol. Ther. 2012, 20, 245-255. [CrossRef]

66. Frenkel, D.; Wilkinson, K.; Zhao, L.; Hickman, S.E.; Means, T.K.; Puckett, L.; Farfara, D.; Kingery, N.D.; Weiner, H.L.; El Khoury, J. Scara1 deficiency impairs clearance of soluble amyloid- $\beta$ by mononuclear phagocytes and accelerates Alzheimer's-like disease progression. Nat. Commun. 2013, 4, 2030. [CrossRef] [PubMed]

67. El Khoury, J.; Hickman, S.E.; Thomas, C.A.; Cao, L.; Silverstein, S.C.; Loike, J.D. Scavenger receptor-mediated adhesion of microglia to beta-amyloid fibrils. Nature 1996, 382, 716-719. [CrossRef] [PubMed]

68. Hong, S.; Beja-Glasser, V.F.; Nfonoyim, B.M.; Frouin, A.; Li, S.; Ramakrishnan, S.; Merry, K.M.; Shi, Q.; Rosenthal, A.; Barres, B.A.; et al. Complement and microglia mediate early synapse loss in Alzheimer mouse models. Science 2016, 352, 712-716. [CrossRef]

69. Mishra, V.K.; Shih, H.H.; Parveen, F.; Lenzen, D.; Ito, E.; Chan, T.F.; Ke, L.Y. Identifying the Therapeutic Significance of Mesenchymal Stem Cells. Cells 2020, 9, 1145. [CrossRef]

70. Venegas, C.; Kumar, S.; Franklin, B.S.; Dierkes, T.; Brinkschulte, R.; Tejera, D.; Vieira-Saecker, A.; Schwartz, S.; Santarelli, F.; Kummer, M.P.; et al. Microglia-derived ASC specks cross-seed amyloid- $\beta$ in Alzheimer's disease. Nature 2017, 552, 355-361. [CrossRef]

71. Hickman, S.E.; El Khoury, J. The neuroimmune system in Alzheimer's disease: The glass is half full. J. Alzheimer's Dis. Jad 2013, 33 (Suppl. S1), S295-S302. [CrossRef]

72. Keren-Shaul, H.; Spinrad, A.; Weiner, A.; Matcovitch-Natan, O.; Dvir-Szternfeld, R.; Ulland, T.K.; David, E.; Baruch, K.; Lara-Astaiso, D.; Toth, B.; et al. A Unique Microglia Type Associated with Restricting Development of Alzheimer's Disease. Cell 2017, 169, 1276-1290.e1217. [CrossRef] [PubMed]

73. Dickson, D.W. Neuropathology of Parkinson disease. Parkinsonism Relat. Disord. 2018, 46 (Suppl. S1), S30-S33. [CrossRef]

74. McGeer, P.L.; Itagaki, S.; Boyes, B.E.; McGeer, E.G. Reactive microglia are positive for HLA-DR in the substantia nigra of Parkinson's and Alzheimer's disease brains. Neurology 1988, 38, 1285-1291. [CrossRef] [PubMed]

75. Daniele, S.G.; Béraud, D.; Davenport, C.; Cheng, K.; Yin, H.; Maguire-Zeiss, K.A. Activation of MyD88-dependent TLR1/2 signaling by misfolded $\alpha$-synuclein, a protein linked to neurodegenerative disorders. Sci. Signal. 2015, 8, ra45. [CrossRef] [PubMed]

76. Kumaran, R.; Cookson, M.R. Pathways to Parkinsonism Redux: Convergent pathobiological mechanisms in genetics of Parkinson's disease. Hum. Mol. Genet. 2015, 24, R32-R44. [CrossRef] [PubMed]

77. Daher, J.P.; Volpicelli-Daley, L.A.; Blackburn, J.P.; Moehle, M.S.; West, A.B. Abrogation of $\alpha$-synuclein-mediated dopaminergic neurodegeneration in LRRK2-deficient rats. Proc. Natl. Acad. Sci. USA 2014, 111, 9289-9294. [CrossRef] [PubMed]

78. Halliday, G.M.; Stevens, C.H. Glia: Initiators and progressors of pathology in Parkinson's disease. Mov. Disord. Off. J. Mov. Disord. Soc. 2011, 26, 6-17. [CrossRef]

79. Turner, M.R.; Cagnin, A.; Turkheimer, F.E.; Miller, C.C.; Shaw, C.E.; Brooks, D.J.; Leigh, P.N.; Banati, R.B. Evidence of widespread cerebral microglial activation in amyotrophic lateral sclerosis: An [11C](R)-PK11195 positron emission tomography study. Neurobiol. Dis. 2004, 15, 601-609. [CrossRef]

80. Henkel, J.S.; Engelhardt, J.I.; Siklós, L.; Simpson, E.P.; Kim, S.H.; Pan, T.; Goodman, J.C.; Siddique, T.; Beers, D.R.; Appel, S.H. Presence of dendritic cells, MCP-1, and activated microglia/macrophages in amyotrophic lateral sclerosis spinal cord tissue. Ann. Neurol. 2004, 55, 221-235. [CrossRef]

81. Beers, D.R.; Henkel, J.S.; Xiao, Q.; Zhao, W.; Wang, J.; Yen, A.A.; Siklos, L.; McKercher, S.R.; Appel, S.H. Wild-type microglia extend survival in PU.1 knockout mice with familial amyotrophic lateral sclerosis. Proc. Natl. Acad. Sci. USA 2006, 103, 16021-16026. [CrossRef]

82. Boillée, S.; Yamanaka, K.; Lobsiger, C.S.; Copeland, N.G.; Jenkins, N.A.; Kassiotis, G.; Kollias, G.; Cleveland, D.W. Onset and progression in inherited ALS determined by motor neurons and microglia. Science 2006, 312, 1389-1392. [CrossRef] [PubMed]

83. Gurney, M.E.; Pu, H.; Chiu, A.Y.; Dal Canto, M.C.; Polchow, C.Y.; Alexander, D.D.; Caliendo, J.; Hentati, A.; Kwon, Y.W.; Deng, H.X.; et al. Motor neuron degeneration in mice that express a human $\mathrm{Cu}, \mathrm{Zn}$ superoxide dismutase mutation. Science 1994, 264, 1772-1775. [CrossRef] [PubMed]

84. Frakes, A.E.; Ferraiuolo, L.; Haidet-Phillips, A.M.; Schmelzer, L.; Braun, L.; Miranda, C.J.; Ladner, K.J.; Bevan, A.K.; Foust, K.D.; Godbout, J.P.; et al. Microglia induce motor neuron death via the classical NF-kB pathway in amyotrophic lateral sclerosis. Neuron 2014, 81, 1009-1023. [CrossRef] [PubMed]

85. Yamanaka, K.; Boillee, S.; Roberts, E.A.; Garcia, M.L.; McAlonis-Downes, M.; Mikse, O.R.; Cleveland, D.W.; Goldstein, L.S. Mutant SOD1 in cell types other than motor neurons and oligodendrocytes accelerates onset of disease in ALS mice. Proc. Natl. Acad. Sci. USA 2008, 105, 7594-7599. [CrossRef]

86. Apolloni, S.; Amadio, S.; Montilli, C.; Volonté, C.; D'Ambrosi, N. Ablation of P2 $\times 7$ receptor exacerbates gliosis and motoneuron death in the SOD1-G93A mouse model of amyotrophic lateral sclerosis. Hum. Mol. Genet. 2013, 22, 4102-4116. [CrossRef]

87. Liao, B.; Zhao, W.; Beers, D.R.; Henkel, J.S.; Appel, S.H. Transformation from a neuroprotective to a neurotoxic microglial phenotype in a mouse model of ALS. Exp. Neurol. 2012, 237, 147-152. [CrossRef] 
88. Meissner, F.; Molawi, K.; Zychlinsky, A. Mutant superoxide dismutase 1-induced IL-1beta accelerates ALS pathogenesis. Proc. Natl. Acad. Sci. USA 2010, 107, 13046-13050. [CrossRef]

89. Harraz, M.M.; Marden, J.J.; Zhou, W.; Zhang, Y.; Williams, A.; Sharov, V.S.; Nelson, K.; Luo, M.; Paulson, H.; Schöneich, C.; et al. SOD1 mutations disrupt redox-sensitive Rac regulation of NADPH oxidase in a familial ALS model. J. Clin. Investig. 2008, 118, 659-670. [CrossRef]

90. Zhao, W.; Beers, D.R.; Henkel, J.S.; Zhang, W.; Urushitani, M.; Julien, J.P.; Appel, S.H. Extracellular mutant SOD1 induces microglial-mediated motoneuron injury. Glia 2010, 58, 231-243. [CrossRef]

91. O’Rourke, J.G.; Bogdanik, L.; Yáñez, A.; Lall, D.; Wolf, A.J.; Muhammad, A.K.; Ho, R.; Carmona, S.; Vit, J.P.; Zarrow, J.; et al. C9orf72 is required for proper macrophage and microglial function in mice. Science 2016, 351, 1324-1329. [CrossRef]

92. O'Rourke, J.G.; Bogdanik, L.; Muhammad, A.; Gendron, T.F.; Kim, K.J.; Austin, A.; Cady, J.; Liu, E.Y.; Zarrow, J.; Grant, S.; et al C9orf72 BAC Transgenic Mice Display Typical Pathologic Features of ALS/FTD. Neuron 2015, 88, 892-901. [CrossRef] [PubMed]

93. Spiller, K.J.; Restrepo, C.R.; Khan, T.; Dominique, M.A.; Fang, T.C.; Canter, R.G.; Roberts, C.J.; Miller, K.R.; Ransohoff, R.M.; Trojanowski, J.Q.; et al. Microglia-mediated recovery from ALS-relevant motor neuron degeneration in a mouse model of TDP-43 proteinopathy. Nat. Neurosci. 2018, 21, 329-340. [CrossRef] [PubMed]

94. Paolicelli, R.C.; Jawaid, A.; Henstridge, C.M.; Valeri, A.; Merlini, M.; Robinson, J.L.; Lee, E.B.; Rose, J.; Appel, S.; Lee, V.M.; et al. TDP-43 Depletion in Microglia Promotes Amyloid Clearance but Also Induces Synapse Loss. Neuron 2017, 95, 297-308. [CrossRef] [PubMed]

95. Voet, S.; Prinz, M.; van Loo, G. Microglia in Central Nervous System Inflammation and Multiple Sclerosis Pathology. Trends Mol. Med. 2019, 25, 112-123. [CrossRef] [PubMed]

96. Kuhlmann, T.; Ludwin, S.; Prat, A.; Antel, J.; Brück, W.; Lassmann, H. An updated histological classification system for multiple sclerosis lesions. Acta Neuropathol. 2017, 133, 13-24. [CrossRef] [PubMed]

97. Yamasaki, R.; Lu, H.; Butovsky, O.; Ohno, N.; Rietsch, A.M.; Cialic, R.; Wu, P.M.; Doykan, C.E.; Lin, J.; Cotleur, A.C.; et al. Differential roles of microglia and monocytes in the inflamed central nervous system. J. Exp. Med. 2014, 211, 1533-1549. [CrossRef]

98. Palpagama, T.H.; Waldvogel, H.J.; Faull, R.L.M.; Kwakowsky, A. The Role of Microglia and Astrocytes in Huntington's Disease. Front. Mol. Neurosci. 2019, 12, 258. [CrossRef]

99. Ghosh, R.; Tabrizi, S.J. Huntington disease. Handb. Clin. Neurol. 2018, 147, 255-278. [CrossRef]

100. Vonsattel, J.P.; Keller, C.; Cortes Ramirez, E.P. Huntington's disease-neuropathology. Handb. Clin. Neurol. 2011, 100, 83-100. [CrossRef]

101. Sapp, E.; Kegel, K.B.; Aronin, N.; Hashikawa, T.; Uchiyama, Y.; Tohyama, K.; Bhide, P.G.; Vonsattel, J.P.; DiFiglia, M. Early and progressive accumulation of reactive microglia in the Huntington disease brain. J. Neuropathol. Exp. Neurol. 2001, 60, 161-172. [CrossRef]

102. Tai, Y.F.; Pavese, N.; Gerhard, A.; Tabrizi, S.J.; Barker, R.A.; Brooks, D.J.; Piccini, P. Microglial activation in presymptomatic Huntington's disease gene carriers. Brain A J. Neurol. 2007, 130, 1759-1766. [CrossRef]

103. Pavese, N.; Gerhard, A.; Tai, Y.F.; Ho, A.K.; Turkheimer, F.; Barker, R.A.; Brooks, D.J.; Piccini, P. Microglial activation correlates with severity in Huntington disease: A clinical and PET study. Neurology 2006, 66, 1638-1643. [CrossRef] [PubMed]

104. Crotti, A.; Benner, C.; Kerman, B.E.; Gosselin, D.; Lagier-Tourenne, C.; Zuccato, C.; Cattaneo, E.; Gage, F.H.; Cleveland, D.W.; Glass, C.K. Mutant Huntingtin promotes autonomous microglia activation via myeloid lineage-determining factors. Nat. Neurosci. 2014, 17, 513-521. [CrossRef] [PubMed]

105. Mackenzie, I.R.; Neumann, M.; Bigio, E.H.; Cairns, N.J.; Alafuzoff, I.; Kril, J.; Kovacs, G.G.; Ghetti, B.; Halliday, G.; Holm, I.E.; et al. Nomenclature and nosology for neuropathologic subtypes of frontotemporal lobar degeneration: An update. Acta Neuropathol. 2010, 119, 1-4. [CrossRef]

106. Chang, M.C.; Srinivasan, K.; Friedman, B.A.; Suto, E.; Modrusan, Z.; Lee, W.P.; Kaminker, J.S.; Hansen, D.V.; Sheng, M. Progranulin deficiency causes impairment of autophagy and TDP-43 accumulation. J. Exp. Med. 2017, 214, 2611-2628. [CrossRef]

107. Arrant, A.E.; Onyilo, V.C.; Unger, D.E.; Roberson, E.D. Progranulin Gene Therapy Improves Lysosomal Dysfunction and Microglial Pathology Associated with Frontotemporal Dementia and Neuronal Ceroid Lipofuscinosis. J. Neurosci. Off. J. Soc. Neurosci. 2018, 38, 2341-2358. [CrossRef]

108. Walker, L.C.; Jucker, M. Neurodegenerative diseases: Expanding the prion concept. Annu. Rev. Neurosci. 2015, 38, 87-103. [CrossRef]

109. Yamasaki, T.; Suzuki, A.; Hasebe, R.; Horiuchi, M. Flow Cytometric Detection of PrP(Sc) in Neurons and Glial Cells from Prion-Infected Mouse Brains. J. Virol. 2018, 92. [CrossRef]

110. Falsig, J.; Julius, C.; Margalith, I.; Schwarz, P.; Heppner, F.L.; Aguzzi, A. A versatile prion replication assay in organotypic brain slices. Nat. Neurosci. 2008, 11, 109-117. [CrossRef]

111. Sorce, S.; Nuvolone, M.; Keller, A.; Falsig, J.; Varol, A.; Schwarz, P.; Bieri, M.; Budka, H.; Aguzzi, A. The role of the NADPH oxidase NOX2 in prion pathogenesis. PLoS Pathog. 2014, 10, e1004531. [CrossRef]

112. Aguzzi, A.; Zhu, C. Microglia in prion diseases. J. Clin. Investig. 2017, 127, 3230-3239. [CrossRef] [PubMed]

113. Hafner-Bratkovič, I.; Benčina, M.; Fitzgerald, K.A.; Golenbock, D.; Jerala, R. NLRP3 inflammasome activation in macrophage cell lines by prion protein fibrils as the source of IL-1 $\beta$ and neuronal toxicity. Cell. Mol. Life Sci. Cmls 2012, 69, 4215-4228. [CrossRef] [PubMed] 
114. Xie, W.L.; Shi, Q.; Zhang, J.; Zhang, B.Y.; Gong, H.S.; Guo, Y.; Wang, S.B.; Xu, Y.; Wang, K.; Chen, C.; et al. Abnormal activation of microglia accompanied with disrupted CX3CR1/CX3CL1 pathway in the brains of the hamsters infected with scrapie agent 263K. J. Mol. Neurosci. Mn 2013, 51, 919-932. [CrossRef] [PubMed]

115. Hughes, M.M.; Field, R.H.; Perry, V.H.; Murray, C.L.; Cunningham, C. Microglia in the degenerating brain are capable of phagocytosis of beads and of apoptotic cells, but do not efficiently remove PrPSc, even upon LPS stimulation. Glia 2010, 58, 2017-2030. [CrossRef]

116. Sakai, K.; Hasebe, R.; Takahashi, Y.; Song, C.H.; Suzuki, A.; Yamasaki, T.; Horiuchi, M. Absence of CD14 delays progression of prion diseases accompanied by increased microglial activation. J. Virol. 2013, 87, 13433-13445. [CrossRef]

117. Kouadir, M.; Yang, L.; Tan, R.; Shi, F.; Lu, Y.; Zhang, S.; Yin, X.; Zhou, X.; Zhao, D. CD36 participates in PrP(106-126)-induced activation of microglia. PLoS ONE 2012, 7, e30756. [CrossRef]

118. Shinjo, R.; Imagama, S.; Ito, Z.; Ando, K.; Nishida, Y.; Ishiguro, N.; Kadomatsu, K. Keratan sulfate expression is associated with activation of a subpopulation of microglia/macrophages in Wallerian degeneration. Neurosci. Lett. 2014, 579, 80-85. [CrossRef]

119. Doty, K.R.; Guillot-Sestier, M.V.; Town, T. The role of the immune system in neurodegenerative disorders: Adaptive or maladaptive? Brain Res. 2015, 1617, 155-173. [CrossRef]

120. Abud, E.M.; Ramirez, R.N.; Martinez, E.S.; Healy, L.M.; Nguyen, C.H.H.; Newman, S.A.; Yeromin, A.V.; Scarfone, V.M.; Marsh, S.E.; Fimbres, C.; et al. iPSC-Derived Human Microglia-like Cells to Study Neurological Diseases. Neuron 2017, 94, 278-293. [CrossRef]

121. Ryan, K.J.; White, C.C.; Patel, K.; Xu, J.; Olah, M.; Replogle, J.M.; Frangieh, M.; Cimpean, M.; Winn, P.; McHenry, A.; et al. A human microglia-like cellular model for assessing the effects of neurodegenerative disease gene variants. Sci. Transl. Med. 2017, 9. [CrossRef]

122. Prokop, S.; Miller, K.R.; Drost, N.; Handrick, S.; Mathur, V.; Luo, J.; Wegner, A.; Wyss-Coray, T.; Heppner, F.L. Impact of peripheral myeloid cells on amyloid- $\beta$ pathology in Alzheimer's disease-like mice. J. Exp. Med. 2015, 212, 1811-1818. [CrossRef] [PubMed]

123. Varvel, N.H.; Grathwohl, S.A.; Degenhardt, K.; Resch, C.; Bosch, A.; Jucker, M.; Neher, J.J. Replacement of brain-resident myeloid cells does not alter cerebral amyloid- $\beta$ deposition in mouse models of Alzheimer's disease. J. Exp. Med. 2015, 212, 1803-1809. [CrossRef] [PubMed]

124. Wisniewski, T.; Goñi, F. Immunotherapeutic approaches for Alzheimer's disease. Neuron 2015, 85, 1162-1176. [CrossRef] [PubMed]

125. Sevigny, J.; Chiao, P.; Bussière, T.; Weinreb, P.H.; Williams, L.; Maier, M.; Dunstan, R.; Salloway, S.; Chen, T.; Ling, Y.; et al. The antibody aducanumab reduces A $\beta$ plaques in Alzheimer's disease. Nature 2016, 537, 50-56. [CrossRef] [PubMed]

126. Xiang, X.; Werner, G.; Bohrmann, B.; Liesz, A.; Mazaheri, F.; Capell, A.; Feederle, R.; Knuesel, I.; Kleinberger, G.; Haass, C. TREM2 deficiency reduces the efficacy of immunotherapeutic amyloid clearance. Embo Mol. Med. 2016, 8, 992-1004. [CrossRef] [PubMed]

127. Spangenberg, E.E.; Green, K.N. Inflammation in Alzheimer's disease: Lessons learned from microglia-depletion models. BrainBehav. Immun. 2017, 61, 1-11. [CrossRef]

128. Elmore, M.R.; Najafi, A.R.; Koike, M.A.; Dagher, N.N.; Spangenberg, E.E.; Rice, R.A.; Kitazawa, M.; Matusow, B.; Nguyen, H.; West, B.L.; et al. Colony-stimulating factor 1 receptor signaling is necessary for microglia viability, unmasking a microglia progenitor cell in the adult brain. Neuron 2014, 82, 380-397. [CrossRef]

129. Olmos-Alonso, A.; Schetters, S.T.; Sri, S.; Askew, K.; Mancuso, R.; Vargas-Caballero, M.; Holscher, C.; Perry, V.H.; Gomez-Nicola, D. Pharmacological targeting of CSF1R inhibits microglial proliferation and prevents the progression of Alzheimer's-like pathology. Brain A J. Neurol. 2016, 139, 891-907. [CrossRef]

130. Luo, J.; Elwood, F.; Britschgi, M.; Villeda, S.; Zhang, H.; Ding, Z.; Zhu, L.; Alabsi, H.; Getachew, R.; Narasimhan, R.; et al. Colony-stimulating factor 1 receptor (CSF1R) signaling in injured neurons facilitates protection and survival. J. Exp. Med. 2013, 210, 157-172. [CrossRef]

131. Savage, J.C.; Jay, T.; Goduni, E.; Quigley, C.; Mariani, M.M.; Malm, T.; Ransohoff, R.M.; Lamb, B.T.; Landreth, G.E. Nuclear receptors license phagocytosis by trem2+ myeloid cells in mouse models of Alzheimer's disease. J. Neurosci. Off. J. Soc. Neurosci. 2015, 35, 6532-6543. [CrossRef]

132. Luz, I.; Liraz, O.; Michaelson, D.M. An Anti-apoE4 Specific Monoclonal Antibody Counteracts the Pathological Effects of apoE4 In Vivo. Curr. Alzheimer Res. 2016, 13, 918-929. [CrossRef] [PubMed]

133. Nixon, R.A.; Yang, D.S. Autophagy and neuronal cell death in neurological disorders. Cold Spring Harb. Perspect. Biol. 2012, 4. [CrossRef] [PubMed]

134. Ahmad, L.; Zhang, S.Y.; Casanova, J.L.; Sancho-Shimizu, V. Human TBK1: A Gatekeeper of Neuroinflammation. Trends Mol. Med. 2016, 22, 511-527. [CrossRef] [PubMed]

135. Cho, M.H.; Cho, K.; Kang, H.J.; Jeon, E.Y.; Kim, H.S.; Kwon, H.J.; Kim, H.M.; Kim, D.H.; Yoon, S.Y. Autophagy in microglia degrades extracellular $\beta$-amyloid fibrils and regulates the NLRP3 inflammasome. Autophagy 2014, 10, 1761-1775. [CrossRef] [PubMed] 